Article

\title{
The Role of the UK Green Deal in Shaping Pro-Environmental Behaviours: Insights from Two Case Studies
}

\author{
Candice Howarth $1,2, *$ (D) and Ben M. Roberts ${ }^{2,3}$ (iD) \\ 1 Faculty of Arts and Social Sciences, University of Surrey, Guildford GU2 7XH, UK \\ 2 Global Sustainability Institute, Anglia Ruskin University, Cambridge CB1 1PT, UK; b.m.roberts@lboro.ac.uk \\ 3 School of Architecture, Building and Civil Engineering, Loughborough University, \\ Loughborough LE11 3TU, UK \\ * Correspondence: candice.howarth@surrey.ac.uk; Tel.: +44-(0)-148-368-9371
}

Received: 21 May 2018; Accepted: 19 June 2018; Published: 20 June 2018

\begin{abstract}
Domestic energy use accounts for more than a quarter of total energy use in the United Kingdom (UK), with space and water heating accounting for almost $80 \%$ of this consumption. Energy efficiency is often the simplest and most cost-effective way of reducing energy use, and improving domestic energy efficiency can contribute significantly to reducing the UK's greenhouse gas (GHG) emissions. A significant proportion of the UK's energy stock remains inefficient, and over $80 \%$ of current housing stock will still be standing in 2050. Therefore, retrofitting existing buildings is fundamental to achieving energy efficiency improvements in the domestic sector. In order to reduce carbon emissions and improve domestic energy efficiency, the UK government launched the Green Deal in 2013 to improve the energy efficiency in buildings in the UK, reduce emissions from homes by $29 \%$, and help meet carbon reduction targets. It aimed to overcome existing perceived barriers to the adoption of energy efficiency measures in the home and enable households and businesses to make energy-saving improvements to their properties, delivering a range of important benefits to the owner/occupier as a result. This paper critically assesses the impact of the Green Deal in shaping pro-environmental behaviours by drawing on two case studies. Lessons learnt from the UK's Green Deal energy policy are presented, and implications for the UK government's role in shaping energy policy and pro-environmental behaviours are considered.
\end{abstract}

Keywords: Green Deal; energy policy; pro-environmental behaviour; incentives; energy efficiency

\section{Introduction}

The United Kingdom (UK) government launched the Green Deal in 2013 to improve the energy efficiency of buildings in the UK, reduce emissions from homes by $29 \%$, and help meet carbon reduction targets [1]. The policy aimed to retrofit 14 million homes by 2020, reduce fuel poverty, and create 250,000 jobs [1]. It was the Government's flagship energy efficiency policy for domestic buildings in the Energy Act 2011 [2], replacing energy efficiency schemes such as the Warm Front, the Carbon Emission Reduction Target (CERT), and the Community Energy Saving Programme (CESP). It aimed to overcome perceived barriers to the adoption of energy efficiency measures in the home [3], and enable households and businesses to make energy-saving improvements to their properties, delivering a range of important benefits to the owner/occupier [4]. Much of the UK energy policy on influencing sustainable consumption is guided by the idea that consumers make choices based on their individual best interest $[5,6]$ with an underlying assumption that people use the information available to them to weigh up the positive and negative results of options and make choices accordingly [6]. However, in reality, the choices that people make, and when it comes to energy demand and behaviours, can be inconsistent. For example, loft insulation received substantial 
subsidies under the UK Government's Carbon Emissions Reduction Target (CERT) scheme resulting in a low-capital cost and rapid payback on the installation of loft insulation; therefore, consumers would be expected to install the measure, as it would be in their financial interest to do so [7]. Yet, in June 2015, it was estimated that 30\% of UK homes with lofts did not have at least $125 \mathrm{~mm}$ of loft insulation [8], and research showed that loft insulation could not be given away at zero cost due to a range of barriers [9]. This discrepancy between energy efficiency behaviour and what could be termed economically 'rational' consumer choices suggests that economic barriers such as access to capital, upfront costs, and the relatively cheap cost of energy are not the only factors influencing people's uptake of energy efficiency measures.

\section{Increasing Energy Efficient Behaviour}

Domestic energy use accounts for more than a quarter of total energy use in the UK, with space and water heating comprising almost $80 \%$ of domestic energy use [10]. Energy efficiency is often the simplest and most cost-effective way of reducing energy use, particularly at an individual household level, and improving domestic energy efficiency can therefore contribute significantly to reducing greenhouse gas emissions as well as reducing the costs of meeting renewable energy targets [11]. Retrofitting existing buildings plays an important role; it is recognised by the implementation of the Green Deal, and is fundamental to achieving energy efficiency improvements in the domestic sector, as at least $80 \%$ of the UK's current housing stock will still be standing in 2050 [12]. However, despite nearly 20 years of legislation aimed at improving domestic energy efficiency [13], total energy consumption in the sector in the UK has remained stagnant, with energy efficiency improvements being largely offset by increased demand [14].

\subsection{Barriers to Energy Efficiency}

There is a gap between cost-effective energy efficiency investments and the level of investment that people actually make [15], which is known as the 'energy efficiency gap' [16-20]. This gap demonstrates a failure to take up an option that would be beneficial to individuals [21], and would not exist if householders acted rationally [22]. Domestically, the lack of take-up of energy efficiency behaviours is often caused by barriers that inhibit behaviours that are energy and economically efficient [23], causing consumers to act in a manner that is inconsistent with economic theory [24] and that could be perceived as financially beneficial to them. A literature review was conducted to explore this in greater detail and identify a range of barriers; the outcomes are presented in Table 1.

In 1955, Simon [25] proposed a revision to the thinking of people as rational decision makers. Instead, he offered the notion that people form a 'bounded rationality' whereby optimal decision-making is not conducted due to a complex environment and the limited cognitive ability of the decision maker [25-27]. However, no simple theory can truly reflect every motive that influences decision-making [28]; nonetheless, we explore the concept of energy efficiency behaviours in this paper with an emphasis on the importance of the context of decision-making, which helps shapes people's biases [29]. In addition, this builds on theories around social practices whereby the structures, meanings, and repetition of behaviours (such as cleaning, cooking, and washing, which all have a dependency on energy) lead to practices such as energy consumption [29], providing a useful lens through which to explore energy demand [30].

Research by Niemeyer [31] demonstrated that the main barriers to adoption of new energy efficient behaviours in the home resulted from a lack of knowledge of the behaviour required or relevant technologies available, economic constraints (such as income and the cost of measures), obstacles to making the changes (e.g., time, lack of information, condition of the home, etc.) and demographic characteristics. When it comes to the installation of energy efficiency measures in the home, this becomes more complex, and there are a number of factors that influence decisions. A German study considering energy retrofits of homes found that householders were limited by the financial aspects of a retrofit, specifically investment payback, which drives householder concern as to the direct benefits 
that they will experience from the installation [32]. However, householders invested time to determine whether the rewards of installations are worth the financial investment. Research by BioRegional [33], the Energy Saving Trust, and the Department of Energy and Climate Change (DECC) [34] on a range of UK Pay As You Save (PAYS) pilots where householders were offered different repayment options for the cost of installing energy-efficient products in their homes, found factors such as wanting to improve the condition of their home also drove uptake. Therefore, a variety of barriers and motivators exist at all stages of the consumer journey in relation to domestic energy-related installations, which are defined as pre-consideration, consideration, preparation, and installed (Table 1) [35]. Most importantly perhaps is understanding the relationship between individuals and the technology that they use to reduce energy use [36]. However, this is rarely a central feature underlying the design and implementation of UK energy policy. There is a growing market for home energy-saving products in the UK, although the current usability is questionable, and there is great potential for improvements [37].

Table 1. Energy efficiency barriers.

\begin{tabular}{|c|c|}
\hline Barrier & Description \\
\hline Acceptability & $\begin{array}{l}\text { Fear that installing an energy efficiency measure will restrict freedom of choice [38]. } \\
\text { Measures associated with increased effort or decreased comfort [39]. }\end{array}$ \\
\hline Access to capital & $\begin{array}{l}\text { Not having the means to pay for energy efficiency measures. Even if householders are aware of the } \\
\text { return on investment, a purchase cannot go ahead [40]. It may not alter willingness to pay, but limits } \\
\text { how much householders are willing to spend [41] which can cause a cheaper option being purchased, } \\
\text { which may be sub-optimal in quality [42]. }\end{array}$ \\
\hline Aesthetics & $\begin{array}{l}\text { Choosing a product by looks over functionality [43]. This may manifest itself in the purchase of a new } \\
\text { kitchen instead of an energy efficiency investment because of the greater excitement that this purchase } \\
\text { causes }[44,45] \text {. }\end{array}$ \\
\hline Appearance & $\begin{array}{l}\text { External wall insulation could impact the visual appearance of a house, which some may find } \\
\text { undesirable. For heritage buildings with attractive external features, external wall insulation may not be } \\
\text { permitted due to the significant alteration in appearance this measure causes (see 'regulatory'). }\end{array}$ \\
\hline $\begin{array}{l}\text { Cost-benefit } \\
\text { uncertainty }\end{array}$ & $\begin{array}{l}\text { Householders perceiving costs of the energy efficiency measure to be greater whilst underestimating the } \\
\text { benefits that the measures will deliver }[46,47] \text {. }\end{array}$ \\
\hline Defaults & $\begin{array}{l}\text { People are more likely to accept the default option, which is the option taken if no active choice is made. } \\
\text { This mostly results in no action being taken, even when it is not in the person's best interest [48]. }\end{array}$ \\
\hline $\begin{array}{l}\text { Discounting } \\
\text { the future }\end{array}$ & $\begin{array}{l}\text { Preferring present benefits to those received in the future. The benefits of installing energy-efficiency } \\
\text { measures are accrued over long periods, whilst the costs are immediate [7]. }\end{array}$ \\
\hline Energy price & $\begin{array}{l}\text { Current energy prices are too low to incentivise investment in domestic energy efficiency [49]. Energy } \\
\text { bills occupy a low budget share in proportion to total household expenses [50], with only the fuel-poor } \\
\text { having significant motivation to make their homes more energy-efficient. }\end{array}$ \\
\hline Hidden costs & $\begin{array}{l}\text { Rooted in fear, such as 'trust', hidden costs include the stress and inconvenience of construction mess } \\
\text { ('hassle-factor'), fears that the work will be of poor quality and irreversible, and struggles to find a } \\
\text { suitable installer [14,51]. The hassle-factor could also include the need to clear the loft space before } \\
\text { insulating [52]. }\end{array}$ \\
\hline Income & $\begin{array}{l}\text { High-income households generally consume more energy than low-income households [53]. However, } \\
\text { for higher income households, energy bills account for a lower percentage of outgoings, so they may be } \\
\text { less incentivised to invest. Wealthier householders do not always have concern for making the most } \\
\text { economically efficient decisions, and may be more likely to be wasteful [54]. }\end{array}$ \\
\hline $\begin{array}{l}\text { Lack of } \\
\text { information }\end{array}$ & $\begin{array}{l}\text { Forms 'bounded rationality' [25] whereby decisions are made based on past experience rather than } \\
\text { presently available information [55]. With the right information, householders are more likely to act } \\
\text { rationally [56]. Householders need information on how much they currently spend on energy and how } \\
\text { much they will save by having energy efficiency measures installed [48]. }\end{array}$ \\
\hline Property value & $\begin{array}{l}\text { Energy efficiency improvements do not provide the same increase in home value as visual } \\
\text { improvements such as a new kitchen would [57]. }\end{array}$ \\
\hline Regulatory & $\begin{array}{l}\text { Regulatory barriers, for instance planning regulation on solid wall insulation for homes within a } \\
\text { Conservation Area, can hinder householders making energy efficiency improvements [48]. }\end{array}$ \\
\hline Social norms & $\begin{array}{l}\text { Behaviours expected from others [58] that people use as a benchmark to measure and influence their } \\
\text { own behaviour based on what others are doing [59]. Promoting energy efficiency as a social norm } \\
\text { energy use in the home can be reduced [60]. }\end{array}$ \\
\hline
\end{tabular}


Table 1. Cont.

\begin{tabular}{cl}
\hline Barrier & \multicolumn{1}{c}{ Description } \\
\hline Split incentives & $\begin{array}{l}\text { In the private-rented sector, this manifests itself as a landlord-tenant problem whereby those who } \\
\text { invest in the measure, the landlords, don't benefit from a lower fuel bill [22], and the tenant will not } \\
\text { invest, as they are likely to move out before the benefit of their investment is fully received [61]. }\end{array}$ \\
\hline Tenure & $\begin{array}{l}\text { Whether or not a householder owns their own home or rents affects their willingness to invest in energy } \\
\text { efficiency measures, see 'split incentives'. }\end{array}$ \\
\hline Trust & $\begin{array}{l}\text { The ability to trust stakeholders to act responsibly and for the installed measures to perform as } \\
\text { advertised, and the associated fear that they won't is a barrier to energy efficiency investment [62]. }\end{array}$ \\
\hline \multirow{2}{*}{ Uncertainty } & $\begin{array}{l}\text { Changes to future energy prices and unfamiliar technologies affect the perceived risk. The uncertainty } \\
\text { of achieving savings from an energy efficiency measure because the householder may move house } \\
\text { before reaping the returns through a reduction in energy bill [57]. }\end{array}$ \\
\hline \multirow{2}{*}{$\begin{array}{l}\text { Value-action } \\
\text { gap }\end{array}$} & $\begin{array}{l}\text { The difference between personal values and deeds carried out [63], which lowers motivation to install } \\
\text { energy efficiency measures. 71\% of people are "very or fairly concerned" about climate change [64], } \\
\text { yet a paradox exists where pro-environmental values are not reflected in energy efficiency investments } \\
\text { [65]. This is true even when people feel capable of making a difference to climate change [66]. }\end{array}$ \\
\hline
\end{tabular}

\subsection{The Role of Incentives}

To overcome the energy efficiency gap, appropriately designed incentives to address individual and clusters of barriers (outlined in Table 1) are needed. Saving money on energy bills, saving energy, and concern for the environment were identified as the main drivers for the uptake of energy efficiency measures in a 2007 online survey [67], with the desire for a warmer home driving the uptake of loft insulation. Barriers to the uptake of individual measures vary depending on the measure in question, taking the example of loft insulation, the loss of storage space and the hassle associated with the installation were the main barriers identified. Similarly, the upfront cost of installing loft insulation can be a significant barrier. Therefore, incentives built around removing barriers and increasing drivers are more likely to lead to uptake where a good understanding of how people respond to these incentives exists [68] (Table 2). Using loft clearance as an incentive to overcome the hassle factor barrier to the installation of loft insulation was investigated by Howarth and Jones [52], with a loft clearance trial in partnership with a large DIY chain, and three London local authorities. The study found that the offer of loft clearance, providing it was at an affordable price, could be a suitable solution to overcome the hassle-factor of removing items from the loft before it is insulated.

Table 2. Influences on people's response to incentives (adapted from Metcalf and Dolan [68]).

\begin{tabular}{|c|c|}
\hline Factor & Description \\
\hline Loss aversion & People may be more sensitive to paying $£ 10$ extra on their energy bills than saving $£ 10$. \\
\hline Change focus & $\begin{array}{l}\text { The perceived value of an incentive depends on how big or small the change associated } \\
\text { with gaining the incentive appears from each person's individual reference point. }\end{array}$ \\
\hline Overestimating unlikely events & $\begin{array}{l}\text { Recent experience of not being able to meet finance repayments may affect uptake of a } \\
\text { finance mechanism for domestic energy efficiency improvements. }\end{array}$ \\
\hline Thinking in discrete bundles & $\begin{array}{l}\text { People imagine their money in 'mental accounts', and are reluctant to move money } \\
\text { between mental accounts and treat the money in those accounts differently [69]. } \\
\text { Labelling incentives such as the Winter Fuel Discount encouraged spending on fuel } \\
\text { rather than had it been labelled along with other benefits [70]. }\end{array}$ \\
\hline Negative impacts of incentives & $\begin{array}{l}\text { Care must be taken in the use of incentives to influence positive behaviours, as there is } \\
\text { evidence to suggest that once an activity becomes associated with receiving a reward, } \\
\text { people are less likely to do the same activity in the future without a reward [71]. }\end{array}$ \\
\hline
\end{tabular}

\section{The Green Deal and Increasing Uptake of Energy Efficiency Measures}

The Green Deal was designed to improve domestic energy efficiency in the UK by encouraging households to install a range of energy efficiency measures to their homes with an incentive structure in place to minimise upfront costs of installations via a loan (at no upfront cost). It would act as a major contribution to improve the energy efficiency of buildings in the UK, reducing carbon emissions 
from homes by $29 \%$ through retrofitting 14 million homes by 2020, reducing fuel poverty, and creating 250,000 jobs [1]. The capital was provided by a private-sector consortium who created the Green Deal Finance Company, and the loan was to be repaid by the bill-payer over a number of years via an additional charge placed on the householder's electricity bill. The charge was tied to the home, rather than the individual who took out the original loan, so occupants could freely change with only the current bill-payer liable for the repayments. The 'golden rule' was a crucial element in the calculation of Green Deal costs by placing a limit on the amount of finance that could be provided based on the predicted energy savings of the installed measures calculated during the Green Deal Assessment phase. This was designed to address one of the most important perceived barriers to uptake: that of upfront and hidden costs (Table 1), and meant that the estimated energy bill savings would cover the cost of the Green Deal loan repayment.

In attempts to address more than just access to finance, the Green Deal involved a guided customer journey (Figure 1) from initial assessment to choosing a contractor to carry out the work, which was hoped would remove the lack of information, uncertainty, and hidden costs barriers [72]. Installer companies were also required to be 'Green Deal-approved' to remove barriers related to the mistrust of providers and the hassle factor. The Green Deal also had the potential to overcome a barrier where householders were unwilling to invest in measures because they may move house before reaping the returns through a reduction in energy bills [57]. The Green Deal, being attached to the property's electricity meter, meant the bill-payer (usually the tenant), receiving the benefits of a more efficient home, repaid the loan whilst living there, and not after they moved out, as with a conventional loan $[14,57]$.

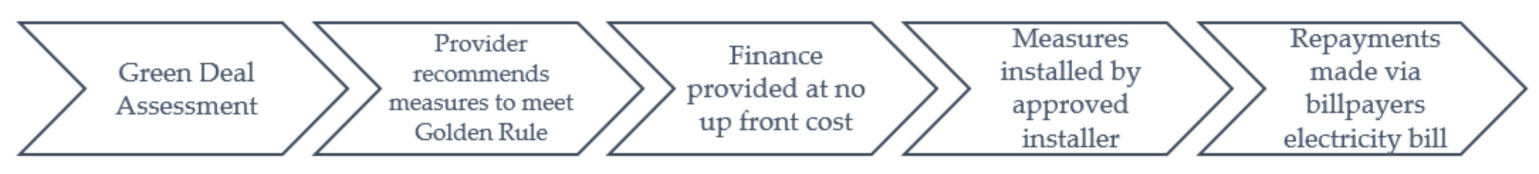

Figure 1. Green Deal customer journey.

This paper critically assesses the impact of the Green Deal in shaping pro-environmental behaviours and presents findings from two government-funded projects to encourage uptake of the Green Deal in England, which were known as Pioneer Places [73]. Discussion of the two case studies is presented: one in Cambridgeshire, UK and another in Suffolk, UK. Motivations for participating in Green Deal activities, perceptions of the assessment process, and general perceptions of the Green Deal are assessed. To incentivise the early uptake of the Green Deal, the government made $£ 10$ million available for local authorities to compete for, of which Cambridgeshire was awarded $£ 75,000$ and Suffolk was awarded $£ 98,000$. Both local authorities used the funding to offer a free Green Deal Assessment, and the authors conducted separate evaluations of the project for the Cambridgeshire and Suffolk local authorities, with the results presented here. The offer of a free Green Deal Assessment was decided upon in response to very early indications from potential Green Deal customers that the assessment cost was a barrier to their involvement with the scheme.

\section{Case Studies}

A case study approach is adopted in this paper, which is defined as "an in-depth, multifaceted investigation, using qualitative research methods, of a single social phenomenon" [74] (p. 2), in which we explore the impact of the Green Deal in shaping low carbon practice. Surveys are used for each as an approach to capture a broad range of data from two relatively large populations. Whilst it is acknowledged that other forms of data collection may be appropriate for similar research (such as interviews and focus groups), due to the nature of the data required (quantitative) and the time and cost limitations associated with this work, surveys are a suitable method to apply. Indeed, this approach has been used widely in research on energy consumption, behaviours, and perceptions, but an awareness 
of its limitations (e.g., response bias, social desirability bias, risk of misinterpretation, etc. [75]), is also required. Based on the assessment of evidence provided in the sections above, we explore the following three themes: (i) motivations for participating in Green Deal and the role of incentives, (ii) perceptions of the assessment process and how this overcomes perceived barriers to change, and (iii) general perceptions of the Green Deal and overall willingness of households to participate. We draw on findings from two case studies, with different samples (Table 3) presented in this section: a Green Deal Assessment pilot project implemented in Cambridgeshire, UK, and a Pioneer Places project in Suffolk, UK.

Table 3. Description of case study data.

\begin{tabular}{ccc}
\hline & $\begin{array}{c}\text { Case Study 1: Green Deal } \\
\text { Assessments in Cambridgeshire }\end{array}$ & $\begin{array}{c}\text { Case Study 2: Pioneer } \\
\text { Places Suffolk }\end{array}$ \\
\hline Green Deal assessments completed & 220 & 500 \\
Questionnaires sent & 165 & 219 \\
Questionnaires completed & 128 & 114 \\
Response rate & $77.6 \%$ & $52 \%$ \\
\hline
\end{tabular}

\subsection{Case Study 1: Green Deal Assessments in Cambridgeshire}

In 2013, The 80 Percent Company, a certified Green Deal Assessor in Cambridge, was commissioned by the Cambridgeshire local authorities to deliver a Green Deal Pioneer Places project. It was designed to kick-start, support, inform, and provide a firm engagement for the long-term delivery of the Green Deal in Cambridgeshire to ensure residents, businesses, and the wider economy could maximise benefits from the Green Deal. Contact with households across Cambridgeshire was acquired through referrals from local authorities $(50 \%)$, community groups, website enquiries, and localised marketing (leafleting and door-knocking). A wide range of property types and ages were sought across the whole of Cambridgeshire, and householders were approached and offered a free assessment. A total of 220 Green Deal assessments were carried out, resulting in the production of independent Energy Advice Reports. An evaluation of the project was carried out via an online questionnaire sent to 165 households in receipt of a free Green Deal Assessment (of which 128 were completed); as well as a high-level evaluation conducted with members of the project team. The questionnaire consisted of 15 questions that were aimed at capturing household's perceptions of the Green Deal Assessment process, and their plans to take up recommended measures. It evaluated the Green Deal Assessments, motivations to participate, perceptions of the impact of energy efficiency measures, experience of energy efficiency installations, awareness of household energy performance, the assessment report, investment into energy efficiency measures, and next steps.

\subsubsection{Motivations for Participating in the Green Deal}

The main motivation for households partaking in the project was to take advantage of the free assessment on offer (98\% agreement); however, other motivators such as wanting to improve the energy efficiency of homes also contributed to this. Over two-thirds of those who had an assessment $(69 \%)$ were already engaged in activities to reduce the energy use in their home, with a small proportion $(8 \%)$ stating they had not undertaken any of the energy efficiency measures listed (insulation, double glazing, draught proofing, heating controls, new boiler, solar panels). The assessment offered in the pilot to households was free, which was a major motivation for participation; however, this was not the case for the Green Deal itself, where households were charged for the assessments. Participants were asked how much they would be prepared to pay for an assessment if they had not already had one. An assessment costing $£ 50$ or more would have been considered by around $41 \%$ of respondents, although over a quarter would not be willing to pay anything for it (Figure 2). 


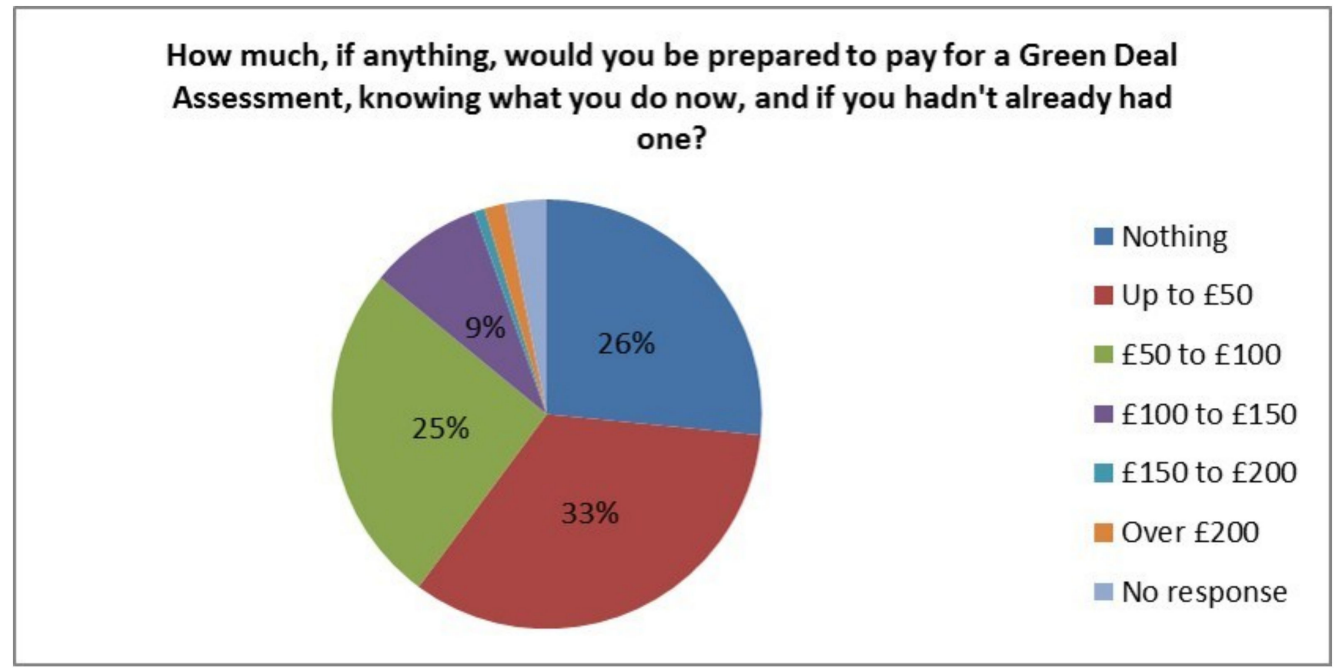

Figure 2. How much Cambridge respondents stated they would be willing to pay for an assessment.

\subsubsection{Perceptions of the Assessment Process and Overcoming Perceived Barriers to Change}

Following the assessment, the majority of participants (87\%) agreed that they had a better idea of how energy-efficient their home was, compared to $54 \%$ before the assessment. Therefore, going through the assessment process appeared to increase understanding of the home's energy efficiency. Assessments were particularly successful in increasing the perceived level of trust in those carrying out the assessment, and the information obtained. Respondents were extremely positive about the process (Figure 3), demonstrating high levels of trust in The 80 Percent Company (88\% agree), and that the information provided was accurate ( $78 \%$ agree). In addition, the endorsement of the work by the local authority was a strong motivator for over $70 \%$ of respondents.

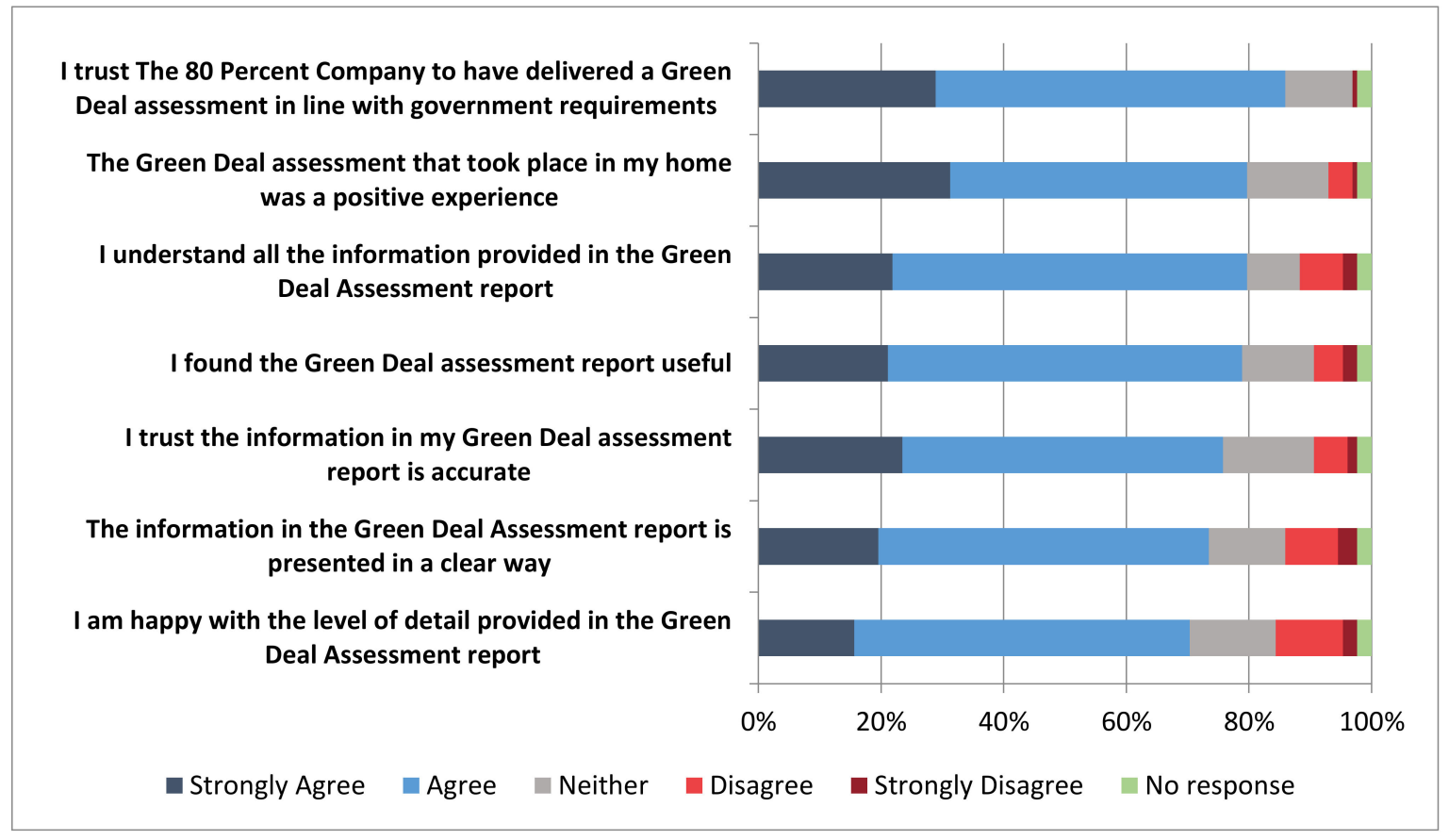

Figure 3. Respondents' perceptions of the assessment experience and report. 
Over two-thirds of households stated that the assessment had recommended something that they had not previously considered before, and $43 \%$ stated that it had increased the importance of home energy efficiency for them, or had changed their opinion about which measure might make the most difference to the energy efficiency of their home. However, a small number of households felt that the level of detail presented in the assessment reports was insufficient to meet their needs. The Green Deal assessment process is intended to remain impartial, offering no specific advice to householders, and this was seen as a limitation. As a result, close to one-third (29\%) of households stated that the lack of information about which energy efficiency measures to install was a reason for not going ahead with the installation process. Over half $(57 \%)$ of the households stated that they needed more time to assess the different options, and $48 \%$ stated that they still needed more information.

Thus, the assessment process was generally a positive one for participants. Most felt better informed afterwards, and the information given was trusted to be accurate, and respondents were also positive about the local assessor involved. However, for many householders, it was not a process through which a final decision was made. Rather, it provided information that householders wanted to consider more. It was found that the Green Deal assessment reports needed to be followed up with discussions with very experienced assessors that understood the shortcomings of the report, and could instill confidence in customers to move forward. However, as assessors were limited in terms of the advisory support that they were allowed to provide, in addition to conducting the assessments, this represents a significant gap in ensuring the information captured in the Green Deal assessments could then be put into practice. This was found to be a significant shortcoming of the reports, in that they needed to be made more relevant to the household and represent accurate and correct measurements and costs (etc.) for all of the properties assessed. It was generally felt to be better to recommend further detailed survey work (beyond the basic Green Deal assessment) to address a household's concerns rather than put forward potentially confusing information.

\subsubsection{General Perceptions of the Green Deal}

Part of the Green Deal assessment process involved the theoretical calculation of the time that it would take the household to pay back the cost of the different measures, thereby increasing the salience of return on the investment of installing measures to householders. The large majority of respondents felt that there was potential for greater home energy efficiency to lead to financial savings for them, with $94 \%$ agreeing that efficiency measures would decrease their bills. There was a slight disappointment with the estimated return on investment calculated in the assessment. Nonetheless, over one-third of respondents also felt they could be better informed about which measures would lead to the highest savings, with $39 \%$ agreeing that they did not know what the most cost-effective measures would be, and a further $21 \%$ neither agreeing nor disagreeing. It was found that highlighting the return on investment alone would not acknowledge that the higher costs of certain measures installed or the non-financial benefits that may emerge. There are a range of other factors that were also highly valued by participants, such as comfort, carbon savings, or supporting local businesses, and these personal motivators were also considered to be a necessity to increase the uptake of measures in addition to financial savings or costs.

The assessment process improved perceptions of the Green Deal (Figure 4), although after the report was received, there was a very slight decrease in positive perception, indicating that for a minority of households, the report was not as comprehensive as they had hoped. 


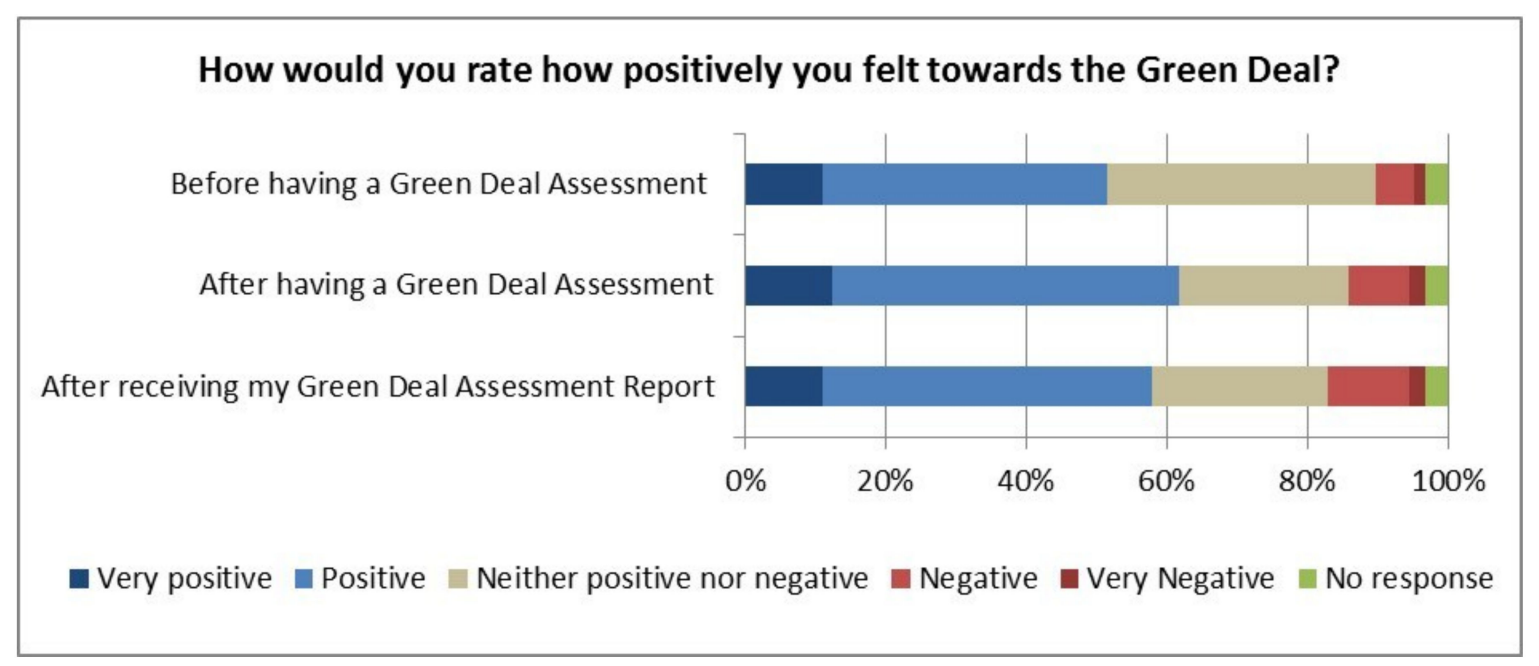

Figure 4. Participants' attitudes toward the Green Deal.

\subsection{Case Study 2: Pioneer Places Suffolk}

In January 2013, the Suffolk County Council's consortium of Suffolk local authorities and a Green Deal provider were commissioned to deliver one of the DECC's Green Deal Pioneer Places pilot schemes to provide 500 free Green Deal assessments to residents in Suffolk. The aim of the pilot was to introduce Suffolk residents to the Green Deal as an innovative and alternative way to improve the energy efficiency of their homes through finance later repaid through their energy bill. Pioneer Places was marketed via a mailshot of 248,244 leaflets sent to every household in Suffolk to promote the scheme in addition to information distributed via local talks, community events, workshops, and online. All 500 free Green Deal assessments were registered for.

A post-assessment online questionnaire was designed with input from consortium partners, containing 30 questions that sought to understand participant demographics; the effectiveness of marketing and branding; resident motivation, perception and awareness of the Green Deal; the assessment process; and future intentions. Questionnaires were sent to 219 householders who received a free Green Deal assessment and provided an email address; a total of 114 questionnaires were completed and returned.

\subsubsection{Motivations for Participating in the Green Deal}

The highest motivating factor for participating in the Pioneer Places scheme was the free assessment, with $80 \%$ agreeing that this was a strong motivator for them to take part (Figure 5). Similarly to the pilot scheme run in Cambridgeshire, a theoretical question was asked to determine how much a customer would be willing to pay for an assessment. Results showed $40 \%$ would not be prepared to pay anything, $28 \%$ would pay up to $£ 50$, and $28 \%$ would pay $£ 50-£ 100$ (Figure 6). The price charged after the Pioneer Places scheme was $£ 80$, and later rose to $£ 129$. Therefore, the assessment cost would likely present a major barrier to uptake, although the government later introduced a $£ 100$ refund for those going ahead with measures, which may have alleviated this problem. A range of other important factors that were also involved in motivating householders to apply for a free Green Deal assessment included "reducing energy use", "making the home more comfortable to live in", "making the home warmer", "reducing energy bills" and the local authority being involved in the scheme. 
What motivated you to participate in the Green Deal Pioneer Places Pilot Project?

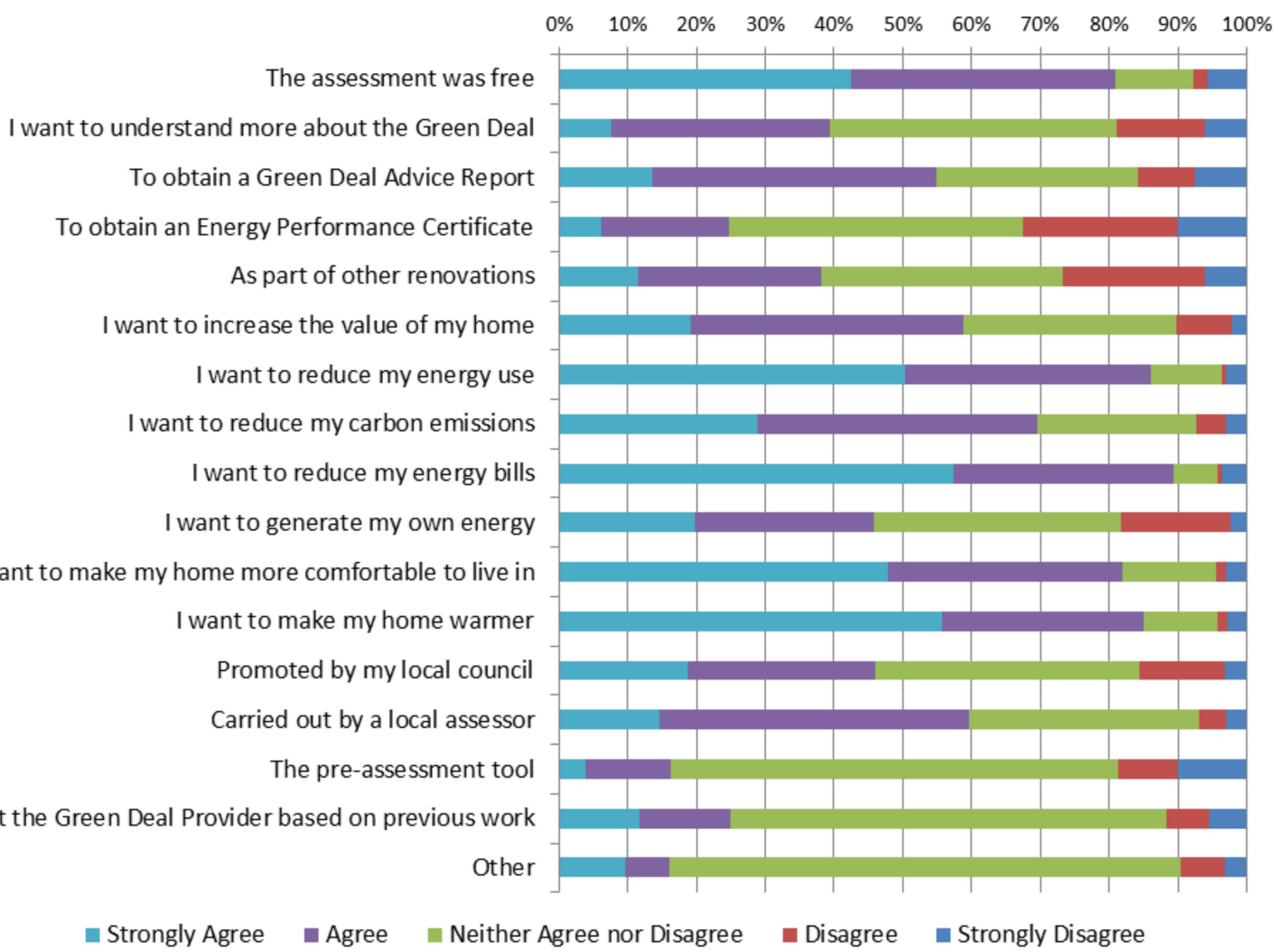

Figure 5. Participants' motivations to participate in Suffolk Green Deal Pioneer Places project.

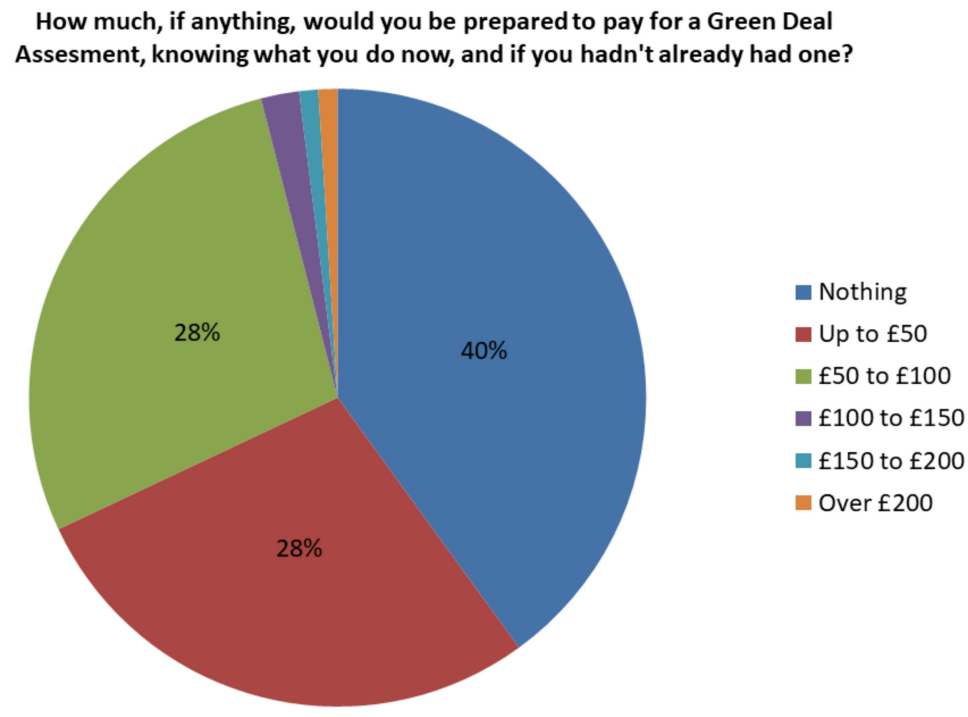

Figure 6. How much Suffolk respondents said they would be willing to pay for an assessment.

\subsubsection{Perceptions of the Assessment Process and Overcoming Perceived Barriers to Change}

The Green Deal assessment is the first experience that a customer has of the Green Deal, and it is important for it to be positive. Therefore, a question asked if the respondent had a "positive assessment experience", to which $75 \%$ agreed. Some participants stated they were unhappy with the way a software package used to produce the assessment reports, and calculated the energy efficiency and potential for Green Deal finance based on assumptions. If participants did not have at least one 
year's worth of energy bills, energy costs were assumed based on house size and the number of occupants, which was at times perceived as problematic, hypothetical, and unrepresentative.

The Green Deal repayment process takes place through the householders' electricity bills and is attached to the house, meaning that when moving house, the repayment becomes the responsibility of the new occupier. Overall, close to half $(45 \%)$ found the idea of repaying the Green Deal loan back via the energy bill appealing, and $37 \%$ found this unappealing. This highly polarised response could reflect the personal circumstances of respondents, and further study is required to determine the precise cause of this. The loan being attached to the house also produced a polarised response, with $32 \%$ finding the loan being attached to the house appealing, and 36\% finding it unappealing. Comments from questionnaire respondents noted concerns regarding a Green Deal loan devaluing their home or discouraging potential buyers. The Green Deal was promoted as a "no upfront cost" scheme, although in reality it did not meet the Golden Rule, as the cost of finance was being met by energy bill savings. This meant that this often wasn't the case, and a customer contribution would be required. For example, double-glazing seemed to be a particular issue due to its relatively high cost, but low energy savings (compared to something such as loft insulation).

\subsubsection{General Perceptions of the Green Deal}

Out of all of the households engaged in the Suffolk Pioneer Places project, 55\% stated that they received no or little improvement in knowledge or understanding of the Green Deal as a result (Figure 7). Greater knowledge and understanding are vitally important in consumers' decision making, as poorly informed consumers form a bounded rationality whereby decisions are made on the basis of past experience [55]. Therefore, people provided with the relevant and appropriate information act more rationally [56], which could increase the uptake of the Green Deal.

Households were given the opportunity to continue with the Green Deal journey beyond the assessment stage. However, this was viewed unfavourably by $60 \%$ of respondents, who said that they would not proceed to apply for Green Deal Finance. Only $14 \%$ agreed that they would take up Green Deal Finance with the issue of a high interest rate being a significant barrier. Respondents commented that cheaper finance was available through other providers, either through extending their mortgage or through other types of loans.

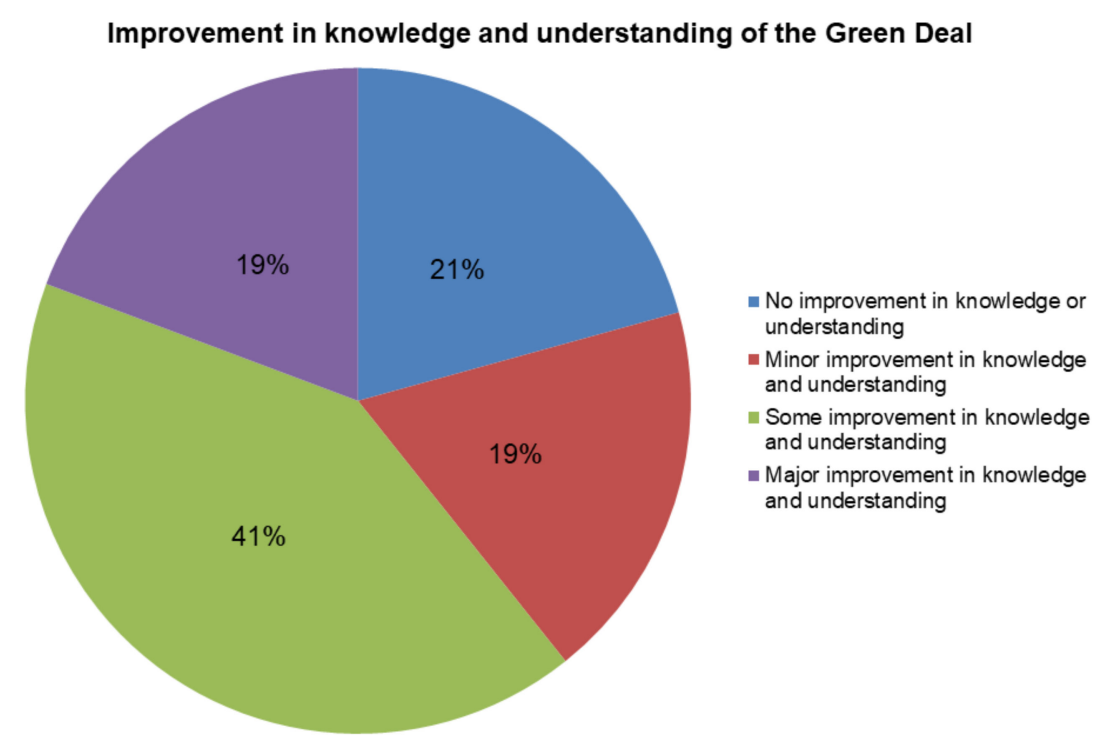

Figure 7. Impact of the assessment on knowledge and understanding of the Green Deal.

In summary, the Green Deal was criticised by participants in the Suffolk Pioneer Places pilot as a complicated policy. Low cost and a desire to improve thermal comfort led to full uptake of the free 
Green Deal assessments offered under Pioneer Places in Suffolk. Initial problems with assessment software, reports being perceived as inaccurate, and not being recommended the energy efficiency improvements that householders wanted may have damaged the first impression of the Green Deal, which gave participants limited confidence to proceed. The negativity surrounding the scheme was compounded by a complex structure and an interest rate that was deemed too high to be attractive.

\section{Discussion: Lessons Learned from the Green Deal}

Overall, the Green Deal Assessment process, as explored in the case studies, was a positive experience for households, although a range of issues were identified throughout this process (demonstrating the value of conducting such pilots), from technical issues in logging Green Deal assessments to delays in households receiving the Green Deal assessment report with mixed feedback on the information provided in the report. Overall, uptake of the free Green Deal assessments was highest amongst households who had a generally high level of energy awareness. Consequentially, targeting low or non-energy aware households and communities could ensure that the Green Deal reaches those who are in the most need of a finance mechanism to install energy efficiency measures.

\subsection{Demonstrated Benefits of Green Deal Assessments}

A key to the success of the case studies was clearly demonstrating the benefit to all those involved: from the householder looking to reduce energy and save money, to the assessor who will have invested resources (financially, time, personnel) to deliver a service of a high standard. The perceived value (including financial) evolved during the process. A quarter of participants stated afterwards that they would not be willing to pay for the Green Deal assessment. However, conversations between households and assessors highlighted that appreciation and value of the assessment increased once it had actually been carried out. Renovations may be a key opportunity when Green Deal assessments could be carried out, or when householders require an energy assessment report (e.g., when renting or selling a house), and may be considered a key investment at these times.

\subsection{Increasing Household Understanding of Energy Use}

The Green Deal process presented a good opportunity to raise awareness of energy efficiency by offering assessments and highlighting energy use and potential for savings within existing properties. Indeed, the assessment process resulted in a higher level or awareness of households of the options that they had for installing energy efficient measures in their homes. However, the most affordable installations offered under the Green Deal were not entirely visible (e.g., loft insulation), similar to the act of using energy, and therefore may not have been as attractive to households who were be unable to visualise the investment made.

\subsection{Local Involvement and Endorsement}

The benefits of the Green Deal pilots being local were twofold: local authority endorsement, as well as local surveyors carrying out the work improved feelings of trust and reliability amongst households, whilst simultaneously providing a strategic advantage to being able to deliver within a known and local geographical area. Locally piloting and testing the crucial front-end of the delivery of the Green Deal in a controlled and less commercially pressurised environment facilitated the management of initial start-up issues, and enabled the freedom to experiment with delivery options with limited exposure to adverse commercial impacts.

Rosenow and Eyre [76] stated that the Green Deal focussed on financial benefits, and contrary to other motivating factors for installing energy efficiency measures in homes, largely ignored personal motivations. Whilst considerable emphasis was placed around the financial benefits of the scheme, the use of local providers who were accredited and approved by the government did go some way to dealing with personal motivations and barriers, as discussed in Table 1. 


\subsection{Barriers, Incentives, and Green Deal Assessments}

The Green Deal itself created a number of barriers that demonstrated its focus on addressing issues of energy demand and supply, and its failure to see the societal need for energy [77]. To recommend suitable energy efficiency measures for a property and calculate predicted energy savings, a Green Deal assessment was required to be carried out, and many companies passed the cost of the assessment onto the customer. Similarly to the two case studies discussed in this paper, Marchand et al. [78] reported an unwillingness of customers to pay more than $£ 50$ for an assessment, with only $30 \%$ of households willing to pay up to $£ 50$, and $28 \%$ unwilling to pay anything. Therefore, the high cost for the Green Deal assessment presented a barrier for the uptake of the Green Deal. This was a particular problem considering that this was part of the first stage in the customer journey, and that the Green Deal was aimed at removing the upfront costs to maximise uptake.

Providing free Green Deal assessments generated initial interest in the process; however, this suggests that interest may have been driven primarily by this rather than increasing understanding of a house's energy performance. The value of the Green Deal assessment evolved throughout the process: it was perceived as lower prior to an assessment taking place, but was later perceived as more valuable once it had been carried out. Assessments took a couple of hours to complete, so finding householders who were available to be present in their property at the time of the assessments was at times challenging when customers were weighing out the value of the assessment compared to their time investment.

The high interest rate was highlighted as a barrier to Green Deal uptake in both case studies. This finding agrees with that of Marchand et al. [78], who showed using 165 resident surveys in Barnsley that consumers were discouraged from using Green Deal finance by such a high rate, and would prefer a much lower rate. Models produced by Guertler [57] show that interest rate levels had a powerful effect on the ability for retrofit works to meet the Golden Rule and that consequently, additional costs were passed onto the consumer. James [14] states that the Green Deal should allow householders to make up the difference between the costs of installed measures and predicted energy savings to help them meet the Golden Rule. However, with the scheme advertised as no upfront cost to the consumer, this provided a confusing message. In the Suffolk pilot scheme, participants were mainly homeowners $(82 \%)$, who were predominantly aged over 45 and in full-time employment, with $50 \%$ reporting a household income of $£ 30,000+$. Their personal circumstances indicated that they may be able to secure a lower interest rate on finance by other means, and that the Green Deal was not the best means of improving the energy efficiency of their home. However, for other demographic groups, Green Deal finance may provide one of the only options for securing finance. Unfortunately, the pilot projects discussed here failed to engage with these socioeconomic groups, which may be indicative of a wider problem of engagement.

\section{Conclusions}

This paper contributes to the literature on energy efficiency retrofit uptake decisions by presenting new evidence of consumer reported experience during the early stages of the Green Deal finance scheme. It highlights the barriers to energy efficiency uptake that the Green Deal addresses, whilst exposing new barriers that the policy creates. The paper has identified a series of barriers to the uptake of energy efficiency measures in homes (Table 1), and considered the role of the Green Deal in overcoming these barriers by analysing two case studies of the Pioneer Places scheme in Cambridgeshire and Suffolk in the United Kingdom. Based on this, we can conclude that whilst the Green Deal pilots were a broadly positive experience for participants with greater understanding of the savings to be made from having energy efficiency measures installed, few would proceed to use Green Deal finance. This has been reflected in other studies $[72,76,78]$ and in the broader failure in the take up of the Green Deal policy as a whole.

The Green Deal focusses on energy efficiency through a lens in which a choice is made to take up energy efficiency measures in the home. Whilst the behavioural dimensions associated with these 
measures (i.e., how people behave in the home once loft insulation or double glazing has been installed) are not fully considered under the Green Deal, the context and practices that affect long-term changes in lifestyle, driving energy consumption in the home, and understanding the social construction of normality [79] do not feature in the mechanisms for the Green Deal. The personal benefits of having energy efficiency measures installed such as improving thermal comfort and decreasing energy bills were seen as attractive aspects of the Green Deal $[78,80]$. However, a lack of awareness about which measures could be installed under the Green Deal was also highlighted as a potential barrier to uptake [78]. Pettifor et al. [72] noted from 502 household surveys before and after the launch of the Green Deal that the proportion of households that was motivated to reduce bills was small compared to the total market, and intentions towards the uptake of energy efficiency measures was weakened by uncertainty around future financial benefits.

A series of motivators and barriers affect the uptake of energy efficiency measures in the home, as listed in Table 1. Personal and immediate motivations such as financial benefits, increasing comfort, increasing energy efficiency, and energy and environmental motivations, as well as removing upfront hassle, were more likely to influence participation in a trial aimed at increasing interest in energy efficiency improvements [52]. Local authority involvement in the two Pioneer Places case studies was clearly identified as a motivating factor for participation, and as a way of increasing trust in such a scheme and attracting participants to the initial offer [81]. This also leads to higher levels of understanding at the community and local authority level; different stakeholders are then able to implement the lessons learnt and successes in future projects.

A failure of the Green Deal Pioneer Places pilot was that very few participants stated that they wished to proceed with the Green Deal process. Whilst the free assessment was a key motivator for participation, as was the increased trust associated with the assessor-local authority partnership for the pilots, the lack of clarity as to how to operationalise the information that was produced in the assessments, and the disappointment concerning return on investment, meant that interest in pursuing the Green Deal was low. Many highlighted the high interest rate, but the personal circumstances of the socioeconomic groups who utilised the pilot scheme meant that they may have had access to cheaper finance elsewhere. Another key failure of the pilots was a failure to engage with householders under the age of 45 , with a lower household income and who were less likely to own their own home. For them, the Green'Deal could be a useful tool to drive pro-environmental behaviour, with improvements to the energy efficiency of their homes.

The Green Deal pilot schemes in Cambridgeshire and Suffolk demonstrated how the Green Deal has the potential to remove a number of barriers to energy efficiency by positively improving participant knowledge, providing contemporary information to avoid bounded rationality, increasing trust with local authority involvement, and the use of accredited companies. The case studies showed that participants felt that having measures installed would reduce their energy bills and felt more aware of which measures would have the greatest benefit. However, the initial motivation to participate was driven by a free-of-charge assessment. The Green Deal does not overcome some barriers such as the issues highlighted around loans affecting property values or overcoming hidden costs from the mess and inconvenience of refurbishment work. Interestingly, the Green Deal introduces barriers of its own in high interest rates, which would affect uptake of the Green Deal by discouraging householders from participating in the first place, and it may have prevented desired measures being installed, because it made it harder to meet the Golden Rule [57]. Therefore, we can conclude that the failure of the Green Deal to be taken up by consumers is in part due to the range of consumer barriers that it fails to address, combined with the contribution that it has made to create new barriers to the uptake of energy efficiency measures in the home, which has created further issues of mistrust amongst consumers.

Author Contributions: Conceptualization, C.H. and B.R.; Methodology, C.H. and B.R.; Formal Analysis, C.H. and B.R.; Writing-Original Draft Preparation, C.H. and B.R.; Writing-Review \& Editing, C.H. and B.R.; Supervision, C.H.

Funding: This research was funded by Cambridgeshire and Suffolk County Councils via the Department of Energy and Climate Change (which merged with the Department for Business, Innovation and Skills in 2016 to 
form the Department for Business, Energy and Industrial Strategy) who commissioned the Global Sustainability Institute to evaluate the Green Deal Pioneer Places project. Additional funding for the co-authors time came from the Low Carbon Knowledge Transfer East of England Partnership Scheme via the European Regional Development Fund.

Acknowledgments: We would like to thank those who participated in the work for their contributions which helped shape this research. Additional thanks are extended to Rosie Robison as well as the anonymous reviewers, whose useful comments informed the final version of this manuscript.

Conflicts of Interest: The authors declare no conflict of interest. The founding sponsors had no role in the design of the study; in the collection, analyses, or interpretation of data; in the writing of the manuscript, and in the decision to publish the results.

\section{References}

1. Department of Energy and Climate Change (DECC). The Green Deal and Energy Company Obligation Impact Assessment; Department of Energy and Climate Change: London, UK, 2011.

2. Her Majesty's Government (HMG). Energy Act 2011. Chapter 16. Part 1: Energy Efficiency, Chapter 1: Green Deal; The Stationary Office, Her Majesty's Government: London, UK, 2011.

3. DECC. The Energy Efficiency Strategy: The Efficiency Opportunity in the UK; Department of Energy and Climate Change: London, UK, 2012.

4. DECC. The Green Deal-A Summary of the Government's Proposals; Department of Energy and Climate Change: London, UK, 2010.

5. Jackson, T. Motivating Sustainable Consumption: A Review of Evidence on Consumer Behaviour and Behavioural Change. A Report to the Sustainable Development Research Network; Sustainable Development Research Network: Guildford, UK; Surrey, UK, 2005.

6. Chatterton, T. An Introduction to Thinking about 'Energy Behaviour': A Multi-Model Approach; Department of Energy and Climate Change: London, UK, 2011.

7. Frederiks, E.R.; Stenner, K.; Hobman, E.V. Household energy use: Applying behavioural economics to understand consumer decision-making behaviour. Renew. Sustain. Energy Rev. 2015, 41, 1385-1394. [CrossRef]

8. DECC. Domestic Green Deal, Energy Company Obligation and Insulation Levels in Great Britain; Statistical Release: National Statistics; Department of Energy and Climate Change: London, UK, 2015.

9. Consumer Focus. What's in It for Me? Using the Benefits of Barriers to Energy Efficiency to Overcome the Barriers; Consumer Focus: London, UK, 2012.

10. The Department for Business, Energy and Industrial Strategy (BEIS). Energy Consumption in the UK; The Department for Business, Energy and Industrial Strategy: London, UK, 2017.

11. Willis, R.; Eyre, N. Demanding Less: Why We Need a New Politics of Energy; Green Alliance: London, UK, 2011.

12. Herring, H. Living in a Low-Carbon Society in 2050; Palgrave-Macmillan: London, UK, 2012.

13. HMG. Home Energy Conservation Act 1995; The Stationery Office, Her Majesty's Government: London, UK, 1995.

14. James, P. Overcoming barriers to low carbon dwellings: The need for innovative models of finance and service-provision. Environ. Dev. 2012, 2, 6-17. [CrossRef]

15. Sorrell, S.; Schleich, J.; Scott, S.; O’Malley, E.; Trace, F.; Boede, U.; Ostertag, K.; Ragden, P. Reducing Barriers to Energy Efficiency in Public and Private Sector Organisations; Science Policy Research Unit (SPRU): Brighton, UK, 2000.

16. Hirst, E.; Brown, M. Closing the efficiency gap: Barriers to the efficient use of energy. Resour. Conserv. Recycl. 1990, 3, 267-281. [CrossRef]

17. Jaffe, A.B.; Stavins, R.N. The energy-efficiency gap: What does it mean? Energy Policy 1994, 22, 804-810. [CrossRef]

18. Backlund, S.; Thollander, P.; Palm, J.; Ottoson, M. Extending the energy efficiency gap. Energy Policy 2012, 51, 392-396. [CrossRef]

19. Pelenur, M.J.; Cruickshank, H.J. Closing the energy efficiency gap: A study linking demographics with barriers to adopting energy efficiency measures in the home. Energy 2012, 47, 348-357. [CrossRef]

20. Wilson, C.; Crane, L.; Chryssochoidis, G. Why do homeowners renovate energy efficiently? Contrasting perspectives and implications for policy. Energy Res. Soc. Sci. 2015, 7, 12-22. [CrossRef] 
21. Fisher, A.C.; Rothkopf, M.H. Market failure and energy policy: A rationale for selective conservation. Energy Policy 1989, 17, 397-406. [CrossRef]

22. Shove, E. Gaps, barriers and conceptual chasms. Energy Policy 1998, 26, 1105-1112. [CrossRef]

23. Sorrell, S.; Mallet, A.; Nye, S. Barriers to Industrial Energy Efficiency: A Literature Review; UNIDO Working Paper 10; United Nations Industrial Development Organization (UNIDO): Vienna, Austria, 2011.

24. Thaler, R. Toward a positive theory of consumer choice. J. Econ. Behav. Organ. 1980, 1, 39-60. [CrossRef]

25. Simon, H.A. A behavioural model of rational choice. Q. J. Econ. 1955, 69, 99-118. [CrossRef]

26. Simon, H.A. Rational choice and the structure of the environment. Psychol. Rev. 1956, 63, 129-138. [CrossRef] [PubMed]

27. Simon, H.A. Models of Man: Social and Rational; Mathematical Essays on Rational Human Behavior; Wiley: New York, NY, USA, 1957.

28. Loewenstein, G.; Prelec, D. Anomalies intertemporal choice: Evidence and an interpretation. Q. J. Econ. 1992, 107, 573-597. [CrossRef]

29. Della Valle, N.; Bisello, A.; Balest, J. In search of behavioural and social levers for effective social housing retrofit programs. Energy Build. 2018, 172, 517-524. [CrossRef]

30. Shove, E. Energy and Social Practice: From Abstractions to Dynamic Processes. In Complex Systems and Social Practices in Energy Transitions; Labanca, N., Ed.; Springer: Cham, Switzerland, 2017; pp. 207-220.

31. Niemeyer, S. Consumer voices: Adoption of residential energy-efficient practices. Int. J. Consum. Stud. 2010, 34, 140-145. [CrossRef]

32. Climate Policy Initiative (CPI). Drivers of Thermal Retrofit Decisions-A Survey of German Single-and Two-Family Houses; Climate Policy Initiative: Berlin, Germany, 2011.

33. BioRegional. Helping to Inform the Green Deal: Green Shoots from Pay as You Save; Sutton Pilot and Evaluation Report; BioRegional: London, UK, 2011.

34. DECC; Energy Saving Trust (EST). Home Energy Pay as You Save Pilot Review; Department of Energy and Climate Change/Energy Saving Trust: London, UK, 2011.

35. Purple Market Research. Uptake of Renewable Heat and Energy-The Consumer Journey; Report for the Energy Saving Trust; EST: London, UK, 2011.

36. Higginson, S.; Richardson, I.; Thomson, M. Energy use in the context of behaviour and practice: The interdisciplinary challenge in modelling exible electricity demand. In Proceedings of the Energy and People: Future, Complexity and Challenges, Oxford University, Oxford, UK, 20-21 September 2011.

37. Walker, G.; Taylor, A.; Whittet, C.; Lynn, C.; Docherty, C.; Stephen, B.; Owens, E.; Galloway, S. A practical review of energy saving technology for ageing populations. Appl. Econ. 2017, 62, 247-258. [CrossRef] [PubMed]

38. Steg, L.; Dreijerink, L.; Abrahamse, W. Why are energy policies acceptable and effective? Environ. Behav. 2006, 38, 92-111. [CrossRef]

39. Poortinga, W.; Spence, A.; Demski, C.; Pidgeon, N.F. Individual-motivational factors in the acceptability of demand-side and supply-side measures to reduce carbon emissions. Energy Policy 2012, 48, 812-819. [CrossRef]

40. Reddy, S.B. Overcoming the energy efficiency gap in India's household sector. Energy Policy 2003, 31, 1117-1127. [CrossRef]

41. Liebe, U.; Preisendörfer, P.; Meyerhoff, J. To pay or not to pay: Competing theories to explain individuals willingness to pay for public environmental goods. Environ. Behav. 2011, 43, 106-130. [CrossRef]

42. Rutherford, J.P.; Scharpf, E.W.; Carrington, C.G. Linking consumer energy efficiency with security of supply. Energy Policy 2007, 35, 3025-3035. [CrossRef]

43. Townsend, C.; Sood, S. Self-affirmation through the choice of highly aesthetic products. J. Consum. Res. 2012, 39, 415-428. [CrossRef]

44. Chitturi, R.; Raghunathan, R.; Mahajan, V. Delight by design: The role of hedonic versus utilitarian benefits. J. Mark. 2008, 72, 48-63. [CrossRef]

45. Mogilner, C.; Aaker, J.; Kamvar, S.D. How happiness affects choice. J. Consum. Res. 2012, 39, 429-443. [CrossRef]

46. Oxera. Policies for Energy Efficiency in the UK Household Sector; Report Prepared for DEFRA; Oxera: Oxford, UK, 2006. 
47. Menassa, C.C. Evaluating sustainable retrofits in existing buildings under uncertainty. Energy Build. 2011, 43, 3576-3583. [CrossRef]

48. NERA. Evaluation of Supplier Obligation Policy Options: Report for DTI and Defra; NERA Economic Consulting: White Plains, NY, USA, 2007.

49. Beheiry, S.; Chong, W.; Haas, C. Examining the business impact of owner commitment to sustainability. J. Constr. Eng. Manag. 2006, 132, 384-392. [CrossRef]

50. Verbruggen, A. Stalemate in energy markets: Supply extension versus demand reduction. Energy Policy 2003, 31, 1431-1440. [CrossRef]

51. Weiss, J.; Dunkelberg, E.; Vogelpohl, T. Improving policy instruments to better tap into homeowner refurbishment potential: Lessons learned from a case study in Germany. Energy Policy 2012, 44, 406-415. [CrossRef]

52. Howarth, C.; Jones, A. Increasing Uptake of Household Energy Efficiency Measures: Removing the Hassle Factor Associated with Loft Insulation; Report for the Department of Energy and Climate Change; DECC: London, UK, 2013.

53. Carlsson-Kanyama, A.; Lindén, A.-L.; Eriksson, B. Residential energy behaviour: Does generation matter? Int. J. Consum. Stud. 2005, 29, 239-253. [CrossRef]

54. Blumstein, C.; Kreig, B.; Schipper, L.; York, C. Overcoming social and institutional barriers to energy conservation. Energy 1980, 5, 355-372. [CrossRef]

55. Trianni, A.; Cagno, E. Dealing with barriers to energy efficiency and SMEs: Some empirical evidence. Energy 2012, 37, 494-504. [CrossRef]

56. Tetlow, R.M.; Beaman, C.P.; Elmualim, A.A.; Couling, K. The impact of occupant behaviour on the variation between design and in-use energy consumption of non-domestic buildings: An experimental approach. In Proceedings of the TSBE Conference, Bristol, UK, 3 July 2012.

57. Guertler, P. Can the Green Deal be fair too? Exploring new possibilities for alleviating fuel poverty. Energy Policy 2012, 49, 91-97. [CrossRef]

58. Dolan, P.; Hallsworth, M.; Halpern, D.; King, D.; Metcalfe, R.; Vlaey, I. Influencing behaviour: The mindspace way. J. Econ. Psychol. 2012, 33, 264-277. [CrossRef]

59. Schultz, P.W.; Nolan, J.M.; Cialdini, R.B.; Goldstein, N.J.; Griskevicius, V. The Constructive, Destructive, and Reconstructive Power of Social Norms. Psychol. Sci. 2007, 18, 429-434. [CrossRef] [PubMed]

60. Allcott, H. Social norms and energy conservation. J. Public Econ. 2011, 95, 1082-1095. [CrossRef]

61. Howarth, R.B.; Andersson, B. Market barriers to energy efficiency. Energy Econ. 1993, 15, 262-272. [CrossRef]

62. Ricci, M.; Bellaby, P.; Flynn, R. Engaging the public on paths to sustainable energy: Who has to trust whom? Energy Policy 2010, 38, 2633-2640. [CrossRef]

63. Whitmarsh, L. Scepticism and uncertainty about climate change: Dimensions, determinants and change over time. Glob. Environ. Chang. 2011, 21, 690-700. [CrossRef]

64. Reser, J.P.; Bradley, G.L.; Glendon, A.I.; Ellul, M.C.; Callaghan, R. Public Risk Perceptions, Understandings and Responses to Climate Change in Australia and Great Britain; National Climate Change Adaptation Research Facility: Gold Coast, QLD, Australia, 2012.

65. Owens, S.; Driffill, L. How to change attitudes and behaviours in the context of energy. Energy Policy 2008, 36, 4412-4418. [CrossRef]

66. Hornsey, M.J.; Fielding, K.S.; McStay, R.; Reser, J.P.; Bradley, G.L.; Greenaway, K.H. Evidence for motivated control: Understanding the paradoxical link between threat and efficacy beliefs about climate change. J. Environ. Psychol. 2015, 42, 57-65. [CrossRef]

67. Herring, H.; Caird, S.; Roy, R. Can consumers save energy? Results from surveys of consumer adoption and use of low and zero carbon technologies. In Proceedings of the European Council for an Energy Efficient Economy Summer Study, Côte d'Azur, France, 4-5 June 2007.

68. Metcalfe, R.; Dolan, P. Behavioural economics and its implications for transport. J. Transp. Geogr. 2012, 24, 503-511. [CrossRef]

69. Thaler, R. Mental accounting matters. J. Behav. Decis. Mak. 1999, 12, 183-206. [CrossRef]

70. Beatty, T.; Blow, L.; Crossley, T.; O’Dea, C. Cash by Any Other Name? Evidence on Labelling from the UK Winter Fuel Payment; Institute of Fiscal Studies Working Paper; Institute of Fiscal Studies: London, UK, 2011.

71. Benabou, R.; Tirole, J. Intrinsic and extrinsic motivation. Rev. Econ. Stud. 2003, 70, 489-520. [CrossRef] 
72. Pettifor, H.; Wilson, C.; Chryssochoidis, G. The appeal of the green deal: Empirical evidence for the influence of energy efficiency policy on renovating homeowners. Energy Policy 2015, 79, 161-176. [CrossRef]

73. DECC. £46 Million Boost for 132 Local Energy Schemes; Press Notice: 13/007; Department of Energy and Climate Change: London, UK, 2013.

74. Feagin, J.R.; Orum, E.M.; Sjoberg, G. A Case for the Case Study; University of North Caroline Press: Chapel Hill, NC, USA, 1991.

75. Moy, P.; Murphy, J. Problems and prospects in survey research. J. Mass Commun. Q. 2016, 93, $16-37$. [CrossRef]

76. Rosenow, J.; Eyre, N. A post mortem of the Green Deal: Austerity, energy efficiency, and failure in British energy policy. Energy Res. Soc. Sci. 2016, 21, 141-144. [CrossRef]

77. Shove, E.; Walker, I. What is energy for? Social practice and energy demand. Theory Cult. Soc. 2014, 31, 41-58. [CrossRef]

78. Marchand, R.D.; Koh, S.L.; Morris, J.C. Delivering energy efficiency and carbon reduction schemes in England: Lessons from Green Deal Pioneer Places. Energy Policy 2015, 84, 96-106. [CrossRef]

79. Shove, E. Comfort, Cleanliness and Convenience: The Social Organization of Normality; BERG Publishers: Oxford, UK, 2003.

80. Dowson, M.; Poole, A.; Harrison, D.; Susman, G. Domestic UK retrofit challenge: Barriers, incentives and current performance leading into the Green Deal. Energy Policy 2012, 50, 294-205. [CrossRef]

81. Howarth, C.; Jones, A. Insights into the Role of Community-Energy Provider Partnerships on Generating Uptake of Energy Efficient Measures in Households; Report for the Department of Energy and Climate Change; DECC: London, UK, 2013.

(C) 2018 by the authors. Licensee MDPI, Basel, Switzerland. This article is an open access article distributed under the terms and conditions of the Creative Commons Attribution (CC BY) license (http://creativecommons.org/licenses/by/4.0/). 